\title{
Grazing and Songbird Nest Survival in Southwestern Saskatchewan
}

\author{
Jennifer Suzanne Lusk ${ }^{1}$ and Nicola Koper ${ }^{2}$ \\ Authors are ${ }^{1}$ Former Graduate Student and ${ }^{2}$ Associate Professor, Natural Resources Institute, University of Manitoba, Winnipeg, \\ MB R3T 2N2, Canada.
}

\begin{abstract}
Grassland songbird populations are declining, and one reason for this might be livestock management practices in native prairies. Although cattle grazing is a common practice in native mixed-grass prairie, little research has been conducted to date to determine its impact on prairie songbird nest survival. During the summers of 2006-2007, we examined the effects of low- to moderate-intensity cattle grazing typical of the region and nest site vegetation structure on nest survival of five species of ground-nesting songbirds in native mixed-grass prairie in southwestern Saskatchewan, Canada. There was no significant effect of grazing $(P>0.10)$ on Sprague's pipit (Anthus spragueii), Baird's sparrow (Ammodramus bairdii), vesper sparrow (Pooecetes gramineus), lark bunting (Calamospiza melanocorys), or chestnut-collared longspur (Calcarius ornatus) nest survival. All five species used denser vegetation than was generally available $(P \leq 0.001)$. Sprague's pipit nest survival was negatively correlated with vegetation density $(P=0.055)$ and litter depth $(P=0.033)$, and vesper sparrow nest survival was positively correlated with increased visibility from above $(P=0.056)$, but nest survival of the other species was independent of vegetation structure. Our results suggest that low- to moderate-intensity grazing is consistent with the conservation needs of ground-nesting songbirds in mixed-grass prairies of southwestern Saskatchewan.
\end{abstract}

Key Words: ground-nesting birds, livestock, mixed-grass prairie, vegetation structure, wildlife habitat

\section{INTRODUCTION}

Grassland bird populations are declining faster than birds of any other ecosystem in North America (Knopf 1996). Factors contributing to these declines likely include conversion of native prairie for agriculture and degradation and fragmentation of the remaining prairie (Herkert et al. 1996; Brennan and Kuvlesky 2005). In Saskatchewan, $21 \%$ of the original native prairie remains, including $31 \%$ of the mixed-grass ecoregion, which is characterized by speargrass (Stipa comata), blue grama (Bouteloua gracilis), northern wheatgrass (Elymus lanceolatus), and western wheatgrass (Pascopyrum smithii; Hammermeister et al. 2001; Ecological Framework of Canada 2011). From 1970 to 2009, the Breeding Bird Survey recorded significant average annual declines of $2 \%$ on average for Saskatchewan's grassland bird populations (Environment Canada 2010), suggesting that there is an immediate need for conservation and management of these species.

Grassland bird populations may be influenced by the presence of livestock on the landscape, as a significant portion of Saskatchewan's native prairie is managed for cattle grazing (Nernberg and Ingstrup 2005). Birds breeding in native mixedgrass prairie evolved with the disturbance created by grazing bison (Bison bison) and wildfire (Knopf and Samson 1997;

\footnotetext{
Research was funded by Environment Canada and World Wildlife Fund-Canada through the Endangered Species Recovery Fund; Parks Canada; Saskatchewan Environment; the Province of Manitoba; and the University of Manitoba.

Correspondence: Nicola Koper, Natural Resources Institute, University of Manitoba, Winnipeg, MB R3T 2N2, Canada. Email: Nicola.Koper@ad.umanitoba.ca

Current address: Jennifer Lusk, Manitoba Conservation and Water Stewardship, Box 70, 160-123 Main St, Winnipeg, MB R3C 1A5, Canada
}

Manuscript received 31 October 2011; manuscript accepted 15 February 2013.

(c) 2013 The Society for Range Management
Askins 2000), and there is some evidence suggesting that cattle may fulfill some of the ecological functions historically filled by bison (Hart 2001; Derner et al. 2009). Both bison and cattle grazing may increase plant species diversity (Hart 2001; Towne et al. 2005) and heterogeneity of vegetation (Knapp et al. 1999; Derner and Whitman 2009; Harrison et al. 2010) relative to that in ungrazed prairie. Prairie songbird communities have a wide range of habitat requirements, and a heterogeneous vegetation structure can provide varied microhabitats suitable for a range of different species (Knopf 1996; Madden et al. 2000). Cattle grazing has been used as a tool for managing biodiversity and wildlife populations (Kresl et al. 1996); rangeland managers can manipulate cattle grazing intensities to increase vegetation heterogeneity (Derner et al. 2009), which may benefit grassland birds.

In addition to increasing vegetation heterogeneity, grazing can have direct and indirect impacts on prairie songbird nest survival. Cattle grazing can influence the density of small mammal populations and has had positive, negative, or no effects on small mammal abundance, depending on the species, habitat, and grazing intensity (e.g., Matlack et al. 2001; Giuliano and Homyack 2004; Johnston and Anthony 2008). Cattle may cause nest failure through trampling (Renfrew and Ribic 2003) and may even depredate nests (Nack and Ribic 2005). However, trampling and depredation rates in northern mixed-grass prairies are low (e.g., Koper and Schmiegelow 2007), presumably because stocking rates are typically low in these relatively arid regions. This suggests that the effects of livestock are generally indirect through the impact of livestock on vegetation structure (Sutter and Ritchison 2005). Vegetation structure influences small mammal community composition and abundance (Grant et al. 1982; Hayward et al. 1997), which may affect the risk of nest predation (Ackerman 2002). Snake abundance also varies with vegetation structure, and nests 
located closer to snake habitat may have a higher risk of predation (Klug et al. 2010). Predator search efficiency may also be greater in shorter, sparser vegetation (Sutter and Ritchison 2005), and reductions in vegetative cover may reduce the availability of high-quality nest sites, forcing birds to select sites where nests are more vulnerable to predation (Ammon and Stacey 1997). Conversely, shorter vegetation may provide small mammals with less protection from predation, which may lead to lower densities of small mammals and thus lower risks of nest predation in grazed areas (Weidinger 2002).

The majority of songbird nests fail, primarily due to predation (Ricklefs 1969), and evolutionary processes should thus have led to birds developing strategies to avoid detection of nests by predators (Martin 1993). Previous studies have demonstrated that prairie songbirds actively select for nest site vegetation that is taller and denser than is generally available (Sutter 1997; Dieni and Jones 2003; Davis 2005). One hypothesis to explain this pattern is that birds are attempting to reduce the risk of nest predation by selecting for nest sites with greater cover, limiting the availability of visual, auditory, and olfactory cues that predators use to locate nests (Martin 1993). Therefore, cattle grazing may indirectly increase the risk of nest predation by reducing the availability of nest sites with tall, dense vegetation (Sutter and Ritchison 2005).

Many studies have examined the effects of cattle grazing on songbird abundance in prairie habitat, and they have found positive, neutral, and negative effects of grazing on abundance, depending on the species, grazing intensity, and local environmental conditions (e.g., Saab et al. 2005; Nelson et al. 2011). Perhaps surprisingly, the few studies that have examined the role of nest site vegetation structure and/or cattle grazing in songbird nest survival have found variable effects of cover on nest survival in that tall, dense vegetation may lead to either lower or higher nest survival (e.g., Davis 2005; Winter et al. 2005; Jones and Dieni 2007; Koper and Schmiegelow 2007; Kerns et al. 2010). Red-winged blackbird (Agelaius phoeniceus) and Savannah sparrow (Passerculus sandwichensis) nest survival was significantly higher in ungrazed pastures than in continuously grazed and rotationally grazed pastures in nonnative prairie in southwestern Wisconsin (Temple et al. 1999). In Kentucky, grasshopper sparrow (Ammodramus savannarum) had higher nest survival in ungrazed prairie (Sutter and Ritchison 2005). Vesper sparrow (Pooecetes gramineus) nest survival was lower in grazed short-grass steppe in British Columbia (Harrison et al. 2011). In contrast, in primarily nonnative grassland in Montana, western meadowlark (Sturnella neglecta) daily nest mortality rates were similar on grazed and ungrazed plots, whereas Savannah sparrow had higher daily nest mortality rates on grazed plots, where brownheaded cowbird (Molothrus ater) parasitism was higher (Fondell and Ball 2004). We are aware of only two other studies that have compared songbird nest survival in grazed and ungrazed mixed-grass prairie. In North Dakota, there was a negative effect of rotational grazing on Savannah sparrow nest survival, a possible negative effect on clay-colored sparrow (Spizella pallida), and no effect on bobolink (Dolichonyx oryzivorus; Kerns et al. 2010). Nest survival of most passerines was similar in grazed and ungrazed sites in Alberta (Koper and Schmiegelow 2007), although nest survival was lower in ungrazed sites for chestnut-collared longspur (Calcarius ornatus).

To the best of our knowledge, no previous studies have compared Sprague's pipit (Anthus spragueii), Baird's sparrow (Ammodramus bairdii), vesper sparrow, and lark bunting (Calamospiza melanocorys) nest survival in grazed and ungrazed native mixed-grass prairie. This is of management and conservation concern, as all of these species continue to experience long-term population declines (Sauer and Hines 2008). Sprague's pipit and chestnut-collared longspur are listed as "threatened" under the Canadian Species at Risk Act (Government of Canada 2012). The Sprague's pipit recovery strategy specifies that information on land use practices that benefit this species is essential for recovery efforts (Environment Canada 2008b). These four species reflect a range of different habitat preferences. Lark buntings prefer short to medium vegetation (Smith and Smith 1966; Wiens 1970), Sprague's pipits and Baird's sparrows prefer taller vegetation (Madden et al. 2000), and vesper sparrows are generalists that utilize grasslands, croplands, and haylands (Davis and Duncan 1999; McMaster et al. 2005). By evaluating effects of management on nest survival of several diverse species, we can develop grazing management recommendations that concurrently conserve several species, an increasingly common goal in prairie conservation (e.g., Downey et al. 2008).

Initiation of a long-term adaptive management grazing experiment at Grasslands National Park of Canada in Saskatchewan enabled us to conduct a 2-yr study (20062007) to achieve three main objectives: 1) determining differences between used and available nest microhabitats, 2) determining the effects of light to moderate stocking rates of cattle grazing, and 3) determining the effects of nest site vegetation structure on nest survival of five songbird species in native mixed-grass prairie. We compared Sprague's pipit, Baird's sparrow, vesper sparrow, lark bunting, and chestnutcollared longspur nest survival in grazed and ungrazed native mixed-grass prairie. As this region is arid and thus plant productivity is low, we predicted that even though stocking rates were light to moderate, grazing would reduce vegetative cover sufficiently that nests in grazed sites would be more exposed to predators and thus that nest survival would be lower in grazed compared with ungrazed prairie.

\section{METHODS}

The study was located in Grasslands National Park of Canada and adjacent Mankota Community Pastures in southwestern Saskatchewan, Canada. The region is semiarid and annual precipitation averaged $347.7 \mathrm{~mm}$ (Environment Canada 2008a). Riparian shrub communities were dominated by western snowberry (Symphoricarpos occidentalis), prairie rose (Rosa acicularis), sagebrush (Artemisia cana), and Canada bluegrass (Poa compressa). Upland areas were characterized by speargrass, blue grama, northern wheatgrass, June grass (Koeleria macrantha), and western wheatgrass.

Terrestrial predators observed in the area include American badger (Taxidea taxus), coyote (Canus latrans), mice and voles (Peromyscus, Clethrionomys), ground squirrels (Spermophilus tridecemlineatus, Spermophilus richardsonii), and garter snake 
(Thamnophis), all species that are known to depredate songbird nests in other regions (Pietz and Granfors 2000; Renfrew and Ribic 2003). Avian species observed in the study area that are known to depredate nests include Northern harrier (Circus cyaneus; Davis et al. 2012), Buteo species (Grant et al. 2006), short-eared owl (Asio flammeus; Holt 1993), and Western meadowlark (Schaeff and Picman 1988).

The site consisted of 13300 -ha units of gently rolling native mixed-grass prairie (Fig. 1). Grazed and ungrazed pastures were fully interspersed north and south to reduce the likelihood of differences in vegetation or topography influencing the study results but could not be interspersed west and east due to the limited availability of ungrazed prairie. Pasture units were selected to ensure approximately equal proportions of upland, riparian, and lowland habitats relative to other pastures; similar topography among pastures; a minimum of $15 \mathrm{yr}$ of consistent management (i.e., without cattle for ungrazed sites, with cattle for grazed sites); a lack of cross-fencing within 300ha pastures; and a high probability that sites would be available for monitoring over the $12 \mathrm{yr}$ proposed for the project.

The four grazed units are commercially managed for raising beef cattle and are located in the adjacent Mankota Community Pastures. Sites were grazed annually at low to moderate intensity from May to September, with a management goal of moderate intensity grazing. In 2006, the mean stocking rate in the four pastures was 0.452 animal unit months (AUM) $\cdot \mathrm{ha}^{-1}$ (range: $0.247-0.551 \mathrm{AUM} \cdot / \mathrm{ha}^{-1}$. In 2007, the mean stocking rate was $0.450 \mathrm{AUM} \cdot \mathrm{ha}^{-1}$ (range: $0.247-0.541 \mathrm{AUM} \cdot \mathrm{ha}^{-1}$ ). The nine ungrazed units were unfenced, while the four grazed units were 300-ha subsamples within larger fenced pastures.

Within each of the upland and lowland portions of each pasture, we established a randomly selected $300 \times 300$-m nestsearching plot ( $n=26$ plots). Wildfires burned portions of a grazed unit (55.9 ha) and two ungrazed units (110.3 and 3.6 ha) in July 2006, including one upland grazed nest-searching plot. A new plot was established after the fire and searched once that year and in 2007.

We conducted nest searching using the rope-drag method (Davis 2003). Our resources enabled us to search the plots twice between May and August 2006 (first round: May 25June 29; second round: June 30-August 1), and three times between May and July 2007 (first round: May 7-June 14; second round: June 20-July 9; third round: July 10-27). To increase the sample size, in 2007, we moved the plots to areas of higher Sprague's pipit densities if no nests were found during the first round of nest searching and moved some again following the second round if, again, no nests were found. We used 2007 point count survey data from the adaptive management grazing experiment to determine areas of higher Sprague's pipit densities in an attempt to maximize the numbers of nests found (Bleho 2009). "Incidental" nests found in the study area during other research activities were also monitored to increase the sample size. This sampling intensity allowed us to collect at least 31 nests per species to enable us to evaluate effects of grazing on five species but certainly led to our sampling only a subsample of the nests started within the boundaries of each plot.

We limited the study to ground-nesting species. Horned lark (Eremophila alpestris), Savannah sparrow, and western meadowlark had small sample sizes in $2006(n<14)$, so we did not

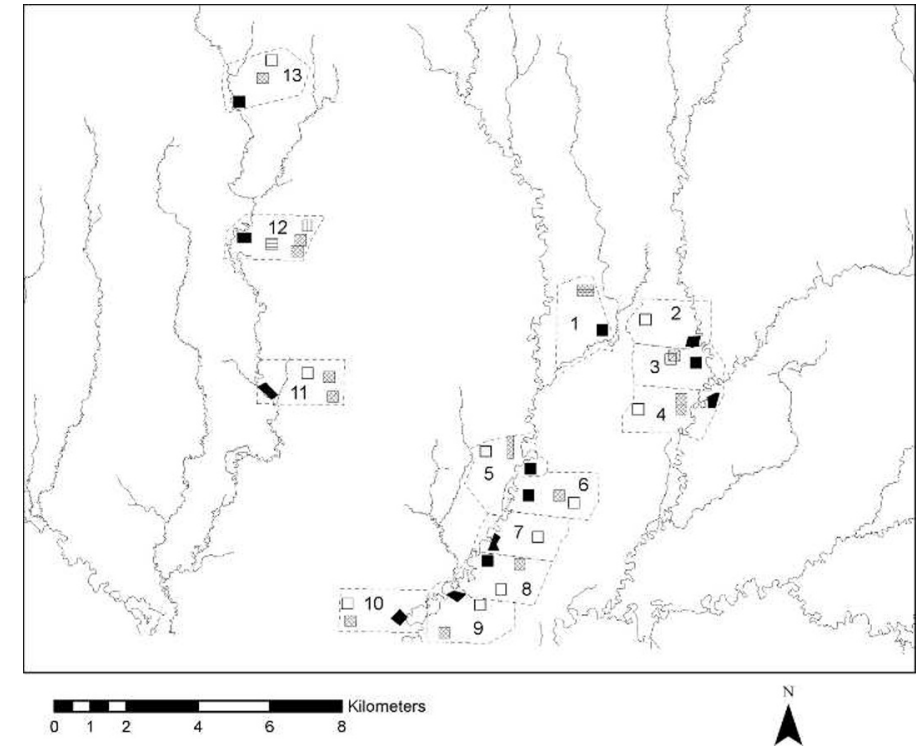

Figure 1. Location of the study area in Grasslands National Park of Canada and adjacent Mankota Community Pastures (lat 49 $10^{\prime} 37^{\prime \prime} \mathrm{N}$, long 107 ${ }^{\circ} 5^{\prime} 33^{\prime \prime}$ W) in southwestern Saskatchewan, Canada, 2006 and 2007. Solid lines indicate streams. Dashed lines indicate adaptive management grazing experiment plots, and areas outlined in black indicate nestsearching plots with solid black areas indicating lowland nest-searching plots and white areas indicating upland nest-searching plots. The plot marked with horizontal lines in unit 12 burned during a wildfire in 2006, and the plot marked with vertical lines replaced it. Areas marked with hatching indicate new upland nest-searching plots established in 2007 based on Sprague's pipit densities from point count surveys (Bleho 2009). In 2006, wildfires burned portions of units 5 (110.3 ha), 6 (3.6 ha), and 12 (55.9 ha).

monitor their nests in 2007. We marked nests with a survey flag $10 \mathrm{~m}$ west of each nest and a bamboo stake $10 \mathrm{~m}$ south of each nest to assist with relocation while minimizing the risk of attracting cattle or predators to the nest (Hein and Hein 1996; Koper and Schmiegelow 2007). Nest locations were also marked using a handheld GPS unit. We monitored all nests every 2-4 d and used behavioral and nest site cues to determine nest success and failure. Nests were considered successful if they fledged at least one young. If nestlings disappeared while too young to fledge, the cause of nest failure was assumed predation (Jones and Dieni 2007).

We collected structural vegetation data within 2 wk of nest termination. We collected data at the nest and at a control site ("available" site) that was used to allow us to compare used versus available habitat. The control vegetation site was randomly located within $50 \mathrm{~m}$ of the nest, which is within the territory size for most of the study species (Maher 1973; Reed 1986; Winter 1999; Fisher and Davis 2011; Jones 2011). We increased the number of control sites per nest to two in 2007. We measured the visibility of the nest cup (at nest sites only) from a meter above using a circular plastic disk $8.9 \mathrm{~cm}$ in diameter, divided into quarters that was placed on top of the nest cup (modified from Davis and Sealy 1998). Vegetation density measurements were centered on the nest or the middle of the control plots. Density was measured using visual obstruction readings taken with a Robel pole (divided into 5- 
$\mathrm{cm}$ increments) $4 \mathrm{~m}$ away from the pole at a height of $1 \mathrm{~m}$ (modified from Robel et al. 1970). Litter depth was measured at the nest with a ruler (Koper and Shmiegelow 2007), with litter defined as any dead vegetation that was not attached to the ground (Sutter 1997).

\section{Statistical Analysis}

Throughout, we use $P$ values from global models to indicate statistical significance and did not use information theory to select best-fitting models. We used $\alpha=0.10$ to reduce the chance of type II errors, which are a serious concern in conservation biology (Taylor and Gerrodette 2002). Because Bonferroni adjustments also increase the risk of type II errors to unacceptably high levels for many ecology studies (Nakagawa 2004), we did not adjust statistical analyses to account for multiple comparisons.

Nest Site Vegetation. We compared used with available nest sites using paired $t$ tests in SAS 9.12 (SAS Institute, Cary, NC). We included all monitored nests regardless of their fate. For the 2007 data, we averaged vegetation structure from the two random sites prior to analyses. We used QQ-plots to confirm normality.

Nest Survival Analyses. All nest survival analyses were conducted using the logistic exposure method in PROC NLMIXED in SAS 9.12 (SAS Institute) following the approach of Shaffer (2004). This analysis approach was developed because researchers use primarily the presence of adult birds to locate nests and are thus less likely to locate nests that fail early in the nesting cycle (Shaffer 2004). As a result, nests that are found and sampled by researchers are more likely to be successful than the overall population of nests, and thus unadjusted nest success parameters are positively biased (Klett and Johnson 1982; Shaffer 2004). The logistic exposure method avoids this problem because it estimates nest survival using only those data from the period during which nests are monitored by the researcher (the exposure period; Shaffer 2004), not the period prior to the nest's being found. To prevent pseudoreplication due to intervals from the same nest being related, we used the number of nests to determine the degrees of freedom as opposed to the number of nest visit intervals. It is possible that there is pseudoreplication within the sample size, as we could not identify renests or second nest attempts (Grant et al. 2006).

Nest survival did not vary among plots for any species except lark bunting, so we did not include plot as a random variable for these species. Nest survival of lark buntings varied among plots, perhaps because the semicolonial behavior of the species alters nest survival among nest clusters. However, models with plot included as a random variable did not converge, so it could not be included in nest survival models.

Preliminary Analyses. We ran preliminary models to determine whether year and seasonality (visit date) influenced daily nest survival (Koper and Schmiegelow 2007) and thus whether these variables should be included in the vegetation and grazing models. We used a polynomial equation to describe the effects of visit date on nest survival, as daily nest survival may vary nonlinearly throughout the season (Rotella et al. 2004; Shaffer 2004). We centered visit date when there was high correlation between linear and quadratic effects of date in the models (Quinn and Keough 2002).

Nest age can influence daily survivorship rates (e.g., Davis 2005). However, it is difficult to confidently assess age of songbird nests during incubation, and we felt it was important to leave unnecessary independent variables out of models to avoid overparameterization. We handled this situation in two ways. First, we ran preliminary models to determine whether nest age, estimated on the basis of the number of eggs present at first visit and/or ages of nestlings at first or subsequent visits, influenced daily nest survival. We included linear, cubic, and quadratic effects of age, as previous studies have found cubic effects of nest age on Baird's sparrow and chestnut-collared longspur (Davis 2005), vesper sparrow (Grant et al. 2005), and lark bunting (Skagen and Yackel Adams 2010). If there were significant effects of age for a species, then we included age in the vegetation structure models. Second, we used a two-sample $t$ test in S-PLUS 6.2 (Tibco, Somerville, MA) to determine whether there was a significant difference in a species' average age in grazed and ungrazed prairie. If there was no significant difference in the average age in grazed and ungrazed prairie, then we did not include nest age in the grazing models, as any increased variance due to nest age was equally dispersed across the treatments and should not confound the results.

Analyses of variance (ANOVAs) showed that vegetation structure in upland habitat was significantly different from that in lowland habitat for all species combined (Lusk 2009), so upland/lowland habitat was included in the vegetation models for all species except lark bunting, which nested only in lowland habitat. ANOVAs also showed that measures of litter depth and visibility from above varied by observer $(P<0.02)$ in 2007. Therefore, we included observer as a variable in the vegetation models.

Grazing, Vegetation, and Nest Survival. Because nest sample sizes available for exploring effects of grazing and effects of vegetation structure differed, we conducted two separate logistic exposure analyses: one that included a grazed/ungrazed binary variable, plus the nuisance variables described above (year, date), and another that included vegetation structure variables (litter depth, vegetation density, and nest cup visibility), plus nuisance variables (year, date, observer, upland/lowland). To ensure that our results were not driven by overparameterization of the models, which was a risk given our relatively small sample sizes, we compared the results of the above models with results of models that excluded the nuisance variables. Including the nuisance variables in the models had no effect on whether the management variables were significant, indicating that our results were not driven by overparameterization. Thus, we present the results including all the variables. We were unable to examine vegetation structure for Baird's sparrow due to small sample size $(n=31)$ and the need to include year and date in the model.

We focused our analyses on nest failure due to predation since it is the primary cause of nest failure (Ricklefs 1969); nests destroyed due to inclement weather or where fate was uncertain were excluded from nest survival analyses. We considered nests parasitized by brown-headed cowbirds successful if they fledged at least one young of the host species. We excluded nests that failed due to brood parasitism $(n=4)$. We 
eliminated nests found in the burned plots from analyses. We excluded nests found during the laying stage from analysis if they were depredated prior to the first nest check, as they may have been abandoned prior to the predation event due to researcher disturbance (Grant et al. 2005). We defined a successful interval as one during which the nest was successful at both the beginning and the end of the observation interval. We removed nest visits that occurred during laying from our analysis so that our results would be comparable with some other studies (e.g. Davis 2003; Grant et al. 2006; Yackel Adams et al. 2007). We used a mean incubation plus nestling period of $25 \mathrm{~d}$ for Sprague's pipit (Davis 2009); 20 d for Baird's sparrow (Ehrlich et al. 1988; Davis 2003; Baicich and Harrison 2005), vesper sparrow (Ehrlich et al. 1988; Baicich and Harrison 2005), and lark bunting (Yackel Adams et al. 2001, 2007); and $22 \mathrm{~d}$ for chestnut-collared longspur (Davis 2003).

We converted parameter estimates and confidence intervals to odds ratios for ease of interpretation. Odds ratios are interpreted as follows: if the odds ratio is more than 1 , such as 1.7, then as the independent variable increases by one unit (e.g., $1 \mathrm{yr})$, the odds of the nest surviving increases by (1-odds ratio $* 100$, in this example, by $70 \%$. If the odds ratio is between 0 and 1 , such as 0.7 , then as the independent variable increases by one unit, the odds of the nest surviving decreases by $(1-$ odds ratio $) * 100$, or $30 \%$ in this example.

\section{RESULTS}

In 2006 and 2007, we found 36 Sprague's pipit, 45 Baird's sparrow, 44 vesper sparrow, 57 lark bunting, and 97 chestnutcollared longspur nests. Predation accounted for $84 \%$ of all known nest failures. Parasitism resulted in the failure of one Baird's sparrow nest and three vesper sparrow nests. We had only one known case of nest failure due to cattle trampling during the $2 \mathrm{yr}$ of the study. Among abandoned nests, we attributed three out of five to severe weather events (i.e., heavy rain and hailstorms). Thirteen nests had an unknown fate.

\section{Nest Site Vegetation}

A subsample of 254 nests was used to explore effects of vegetation on nest survival. All five species had nest sites with significantly greater vegetation density and litter depth than the average available vegetation (Table 1 ).

\section{Preliminary Nest Survival Analyses}

There was no significant effect of year on daily nest survival $(P>0.35)$ except for Baird's sparrow (odds ratio=3.266, $\mathrm{CI}=1.158-9.214, n=31$ ). Nest survival declined during the breeding season for Baird's sparrow (odds ratio $=0.925$, $\mathrm{CI}=0.866-0.987, n=31$ ), lark bunting (odds ratio $=0.942$, $\mathrm{CI}=0.892-0.995, n=50)$, and chestnut-collared longspur (odds ratio $=0.985, \mathrm{CI}=0.968-1.003, n=71$ ) and reached a maximum in the middle of the breeding season for vesper sparrow (odds ratio $=1.028, \mathrm{CI}=1.020-1.036, n=41$ ). Sprague's pipit daily nest survival did not vary with visit date $(P>0.21)$.

Baird's sparrow, vesper sparrow, lark bunting, and chestnutcollared longspur daily nest survival varied with nest age, sometimes nonlinearly and generally declining with nest age

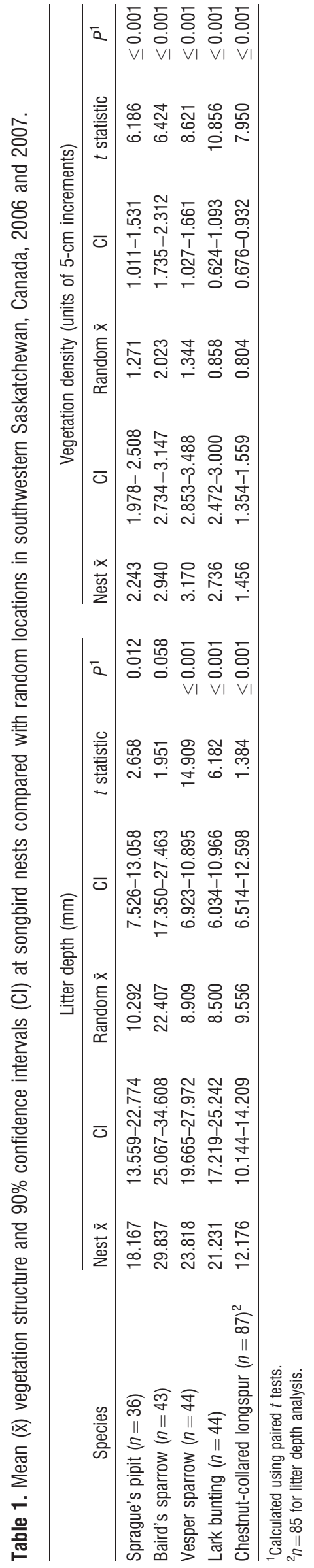


Table 2. Odds ratios and $90 \%$ confidence intervals (Cl) describing daily nest survival of grassland songbirds in grazed prairie relative to ungrazed prairie in southwestern Saskatchewan, Canada, 2006 and $2007 .{ }^{1}$

\begin{tabular}{lcccc}
\hline \multicolumn{1}{c}{ Species } & $n$ & Odds ratio & $\mathrm{Cl}$ & $P$ \\
\hline Sprague's pipit & 31 & 1.456 & $0.393,5.394$ & 0.629 \\
Baird's sparrow $^{2}$ & 31 & 2.187 & $0.564,8.473$ & 0.334 \\
Vesper sparrow $^{3}$ & 41 & 1.853 & $0.872,3.942$ & 0.252 \\
Lark bunting $^{3}$ & 50 & 0.300 & $0.083,1.091$ & 0.124 \\
Chestnut-collared longspur $^{3}$ & 71 & 1.214 & $0.654,2.255$ & 0.602 \\
All species combined $^{2}$ & 224 & 1.133 & $0.810,1.584$ & 0.539 \\
\hline
\end{tabular}

${ }^{1}$ Odds ratios estimated following logistic exposure analyses.

${ }^{2}$ Includes date and year covariates.

${ }^{3}$ Includes date covariates.

(Lusk 2009), so we included nest age in the vegetation models for these species. There was no significant difference $(P \geq 0.13)$ in the average age of nests monitored in grazed and ungrazed prairie for any species, so we did not include nest age in the grazing models.

\section{Grazing, Vegetation, and Nest Survival}

We found 160 nests in grazed prairie and 119 nests in ungrazed prairie. Perhaps because vegetation structure had little effect on nest survival, there was no significant effect of grazing on nest survival for any of the five species in the study for 2006, 2007, or both years combined $(P>0.10$; Table 2$)$. Daily and cumulative nest survival varied among species (Table 3).

Sprague's pipit daily nest survival declined by $76.4 \%$ per 5 $\mathrm{cm}$-increment increase in vegetation density (odds ratio $=0.236, C I=0.069-0.802, n=31$ ). Sprague's pipit daily nest survival also declined by $11 \%$ per $1-\mathrm{mm}$ increase in litter depth (odds ratio $=0.890, \mathrm{CI}=0.816-0.972, n=31$ ). Vesper sparrow daily nest survival increased by $1.8 \%$ per $1 \%$ increment increase in visibility from above (odds ratio $=1.018$, $\mathrm{CI}=1.003-1.033, n=41)$. There were no significant effects of vegetation density, litter depth, or visibility from above on daily nest survival ( $t$ value $\leq-1.46, P>0.10$ ) for lark bunting, chestnut-collared longspur, or all species combined.

\section{DISCUSSION}

Our results did not support our prediction that nest survival would vary between ungrazed and grazed prairies. Stocking rates typical of the northern mixed-grass prairies allow for selective grazing by cattle and result in a relatively patchy vegetation structure (Bleho 2009). This may allow birds to find and use nest sites of similar structure and quality in both grazed and ungrazed prairies (see also Fondell and Ball 2004). Further, because we detected relatively few effects of vegetation structure on nest survival, this suggests that the range of vegetation structure available in these pastures might be sufficient for concealing nests from predators that hunt visually. Cumulatively, this suggests that stocking rates typical of commercial ranches in the northern mixed-grass prairies of southern Saskatchewan are sufficiently low that they neither directly nor indirectly affect nest survival of grassland songbirds.

We caution that the sample sizes for each species were small, and therefore we may not have been able to detect some small differences among treatments. Nonetheless, we feel that our results are informative for two reasons. First, combining our data across species still showed no effect of grazing despite the higher sample size for these analyses, suggesting that our results were not driven by small sample sizes. Second, this is the first study to address effects of grazing on nesting success of Sprague's pipit, Baird's sparrow, vesper sparrow, and lark bunting in mixed-grass prairie; because grassland songbird nests are typically at low densities and thus sample sizes within individual studies are small (e.g., Dieni and Jones 2003; Fondell and Ball 2004; Davis 2005), it is important to initiate this

Table 3. Daily and cumulative songbird nest survival and 90\% confidence intervals $(\mathrm{Cl})$ in grazed and ungrazed native mixed-grass prairie in southwestern Saskatchewan, Canada, 2006 and 2007. ${ }^{1}$

\begin{tabular}{|c|c|c|c|c|c|c|}
\hline \multirow[b]{2}{*}{ Species } & \multirow[b]{2}{*}{ Parameter } & \multirow[b]{2}{*}{$n$} & \multicolumn{2}{|c|}{$\begin{array}{l}\text { Daily nest survival of } \\
\text { successful and predated nests }\end{array}$} & \multicolumn{2}{|c|}{$\begin{array}{l}\text { Cumulative nest survival of } \\
\text { successful and predated nests }\end{array}$} \\
\hline & & & Estimate & $\mathrm{Cl}$ & Estimate & $\mathrm{Cl}$ \\
\hline \multirow[t]{2}{*}{ Sprague's pipit } & Grazed & 14 & 0.989 & $0.978,1.000$ & 0.753 & $0.544,0.965$ \\
\hline & Ungrazed & 17 & 0.984 & $0.970,0.997$ & 0.663 & $0.431,0.894$ \\
\hline \multirow[t]{2}{*}{ Baird's sparrow² } & Grazed & 8 & 0.959 & $0.905,1.012$ & 0.429 & $-0.051,0.909$ \\
\hline & Ungrazed & 23 & 0.910 & $0.862,0.966$ & 0.165 & $-0.022,0.352$ \\
\hline \multirow[t]{2}{*}{ Vesper sparrow ${ }^{3}$} & Grazed & 18 & 0.968 & $0.947,0.989$ & 0.523 & $0.299,0.746$ \\
\hline & Ungrazed & 23 & 0.947 & $0.920,0.975$ & 0.340 & $0.139,0.540$ \\
\hline \multirow[t]{2}{*}{ Lark bunting $^{3}$} & Grazed & 35 & 0.964 & $0.943,0.985$ & 0.482 & $0.272,0.693$ \\
\hline & Ungrazed & 15 & 0.989 & $0.976,1.003$ & 0.803 & $0.585,1.021$ \\
\hline \multirow[t]{2}{*}{ Chestnut-collared longspur ${ }^{3}$} & Grazed & 57 & 0.946 & $0.927,0.965$ & 0.301 & $0.170,0.432$ \\
\hline & Ungrazed & 14 & 0.933 & $0.894,0.972$ & 0.225 & $0.022,0.428$ \\
\hline \multirow[t]{2}{*}{ All species combined } & Grazed & 132 & 0.954 & $0.940,0.967$ & -4 & -4 \\
\hline & Ungrazed & 92 & 0.947 & $0.932,0.964$ & -4 & -4 \\
\hline
\end{tabular}

${ }^{1}$ Odds ratios estimated following logistic exposure analyses.

${ }^{2}$ Includes year and date covariates.

${ }^{3}$ Includes date covariates.

${ }^{4}$ Not calculated as nest period varies by species. 
literature base so that subsequent studies can build on existing knowledge, ultimately allowing a weight of evidence to develop among multiple studies.

Previous studies that have been conducted outside of native mixed-grass prairies provide further support for our conclusion that grazing may not negatively affect nest survival. Our results are consistent with a study in primarily nonnative grasslands in Montana that found that western meadowlark and Savannah sparrow had similar rates of nest predation in grazed and ungrazed sites (Fondell and Ball 2004). While other studies have found higher nest survival in ungrazed prairie (e.g., Temple et al. 1999; Sutter and Ritchison 2005), this may reflect the higher stocking rates and higher stock densities that are typical of more mesic regions and that presumably have a greater impact on vegetation structure (e.g., see trampling rates in Bélanger and Picard 1999). In a similarly arid mixed-grass prairie in southern Alberta, Koper and Schmiegelow (2007) also found little effect of grazing on nest survival of passerines. Our results suggest that cattle grazing in northern mixed-grass prairies-and in southwestern Saskatchewan in particular-may be more compatible with the conservation needs of grassland songbirds than cattle grazing in more mesic regions, perhaps due to differences in stocking rates among these regions.

Cattle grazing appeared to have little direct impact on nest predation in this region. Although cattle may depredate nests (Nack and Ribic 2005) and predators may consume the contents of nests following trampling (Fondell and Ball 2004), in our system this did not lead to a higher predation rate in grazed sites. Cattle destroyed only one nest by trampling and thus had minimal direct impacts on nest survival. Kerns et al. (2010) also found low rates of nest trampling in managed prairie in North Dakota. Higher rates of trampling in other regions (e.g., LaPointe et al. 2000; Renfrew and Ribic 2003) probably reflect the effects of higher stocking rates than those found in the relatively arid northern mixed-grass prairies. Stocking rates typical of ranching in the northern mixed-grass prairies may be low enough that they present little risk to grassland songbird nests.

All five species used nest sites with greater litter depth and vegetation density than was generally available. This is consistent with the results of other studies (Dieni and Jones 2003; Davis 2005). However, in contrast to our predictions, nest survival did not increase with nest concealment. Sprague's pipit nest survival declined with increased vegetation density and litter depth despite the fact that they tended to use nest microhabitats with greater vegetation density and litter depth compared with available microhabitats. In addition, vesper sparrow nest survival increased with greater visibility from above, a result that differs from that of Grant et al. (2006), who found that vesper sparrow nests with greater concealment had higher nest survival in short-grass prairie in British Columbia. Although there was relatively low nest survival during the time frame of our study, it could reflect selection of nest sites that are optimal over the long term (Clark and Shutler 1999) but were suboptimal over the years of the study. Higher nest survival in areas with lower and less dense vegetation might occur because higher small mammal densities are associated with greater cover, which provides protection from their own predators (Murray and Vestal 1979; With 1994; Johnson and Horn 2008). We speculate that if small mammal populations were high during the years of the study, this may have resulted in higher predation risks to nests surrounded by dense cover. Although this may have decreased nest survival in dense vegetation during the years of our study, nest survival may also be influenced by avian predators, snakes, or large mammals, such as coyotes (e.g., see Renfew and Ribic 2003; Klug et al. 2010), and the relative abundance of these species may fluctuate annually. This might lead to higher nest survival in some years in some habitats but lower nest survival in the same habitats in different years. Testing this hypothesis would require more information and years of data than are available to us.

Our results regarding the lack of a correlation between vegetation structure and nest survival for other songbird species is consistent with some studies (Davis 2005; Koper and Schmiegelow 2007) but not others (Lusk et al. 2003; Grant et al. 2006; Jones and Dieni 2007). The lack of a significant effect of vegetation structure on nest survival may result because 1) songbirds had relatively similar vegetation structures regardless of the location of their nest, which may result in a similar risk of predation among nest locations; 2) predation risk is primarily from opportunistic predators and thus may be independent of nest concealment (Vickery et al. 1992); 3) the wide range of predators present in this ecosystem may make it difficult for birds to select safe nest sites (Filliater et al. 1994; Dion et al. 2000); or 4) we did not measure some element of vegetation structure that does, in fact, influence nest survival. The long-term data gathered as part of the ongoing 12-yr adaptive management grazing experiment in the study area will provide further insight into the impact of vegetation structure on songbird nest survival.

\section{IMPLICATIONS}

Our results (and those of other studies) suggest that low to moderate grazing intensity of cattle may be consistent with management and conservation of a range of diverse grassland songbird species in the northern mixed-grass prairies of southwestern Saskatchewan. Further research is required to increase sample sizes and to determine whether this is a local or a regional pattern and the extent to which effects of grazing vary annually. Because all five species used nest sites with taller and denser structure than average, this suggests that ensuring the presence of some tall, dense vegetation on the landscape is important for the conservation of grassland songbirds and that stocking rates and stocking densities should be low enough to allow livestock to forage selectively. Low to moderate grazing intensities typical of southwestern Saskatchewan may allow cattle to forage selectively and maintain a heterogeneous vegetation structure such that grassland songbirds are able to use relatively tall, dense nest sites.

\section{ACKNOWLEDGMENTS}

We thank S. D. Davis and J. W. Wilmshurst for review comments and contributions to this manuscript. Two anonymous reviewers and the Associate Editor provided helpful revisions. L. Armstrong assisted with statistical methods. Field assistance was provided by D. Ash, L. Murray, H. Wheeler, and D. Wiens. Our research methods were approved by the University of Manitoba Animal Care Committee (Protocol F06-005). 


\section{LITERATURE CITED}

ACKerman, J. T. 2002. Of mice and mallards: positive indirect effects of coexisting prey on waterfowl nest success. Oikos 99:469-480.

Ammon, E. M., And P. B. Stacey. 1997. Avian nest success in relation to past grazing regimes in a montane riparian system. Condor 99:7-13.

Askins, R. A. 2000. Restoring North America's birds. New Haven, CT, USA: Yale University Press. $352 \mathrm{p}$.

Baicich, P. J., And J. O. Harrison. 2005. A guide to the nests, eggs, and nestlings of North American birds. San Diego, CA, USA: Academic Press. 347 p.

Bélanger, L., And M. Picard. 1999. Cattle grazing and avian communities of the St. Lawrence River islands. Journal of Range Management 52:332-338.

Bцeno, B. 2009. Passerine relationships with habitat heterogeneity and grazing at multiple scales in northern mixed-grass prairie [thesis]. Winnipeg, MB, Canada: University of Manitoba. $132 \mathrm{p}$.

Brennan, L. A., And W. P. Kuvlesky. 2005. North American grassland birds: an unfolding conservation crisis? Journal of Wildlife Management 69:1-13.

Clark, R. G., and D. ShutLer. 1999. Avian habitat selection: pattern from process in nest-site use by ducks? Ecology 80:272-287.

Davis, S. K. 2003. Nesting ecology of mixed-grass prairie songbirds in southern Saskatchewan. Wilson Bulletin 115:119-130.

DavIs, S. K. 2005. Nest-site selection patterns and the influence of vegetation on nest survival of mixed-grass prairie passerines. Condor 107:605-616.

Davis, S. K. 2009. Renesting intervals and duration of the incubation and nestling periods of Sprague's pipits. Journal of Field Ornithology 80:265-269.

Davis, S. K., AND D. C. Duncan. 1999. Grassland songbird occurrence in native and crested wheatgrass pastures of southern Saskatchewan. Studies in Avian Biology 19:211-218

Davis, S. K., S. L. Jones, K. M. Dohms, and T. G. Holmes. 2012. Identification of Sprague's pipit nest predators. Studies in Avian Biology 43:173-182.

Davis, S. K., AND S. G. Sealy. 1998. Nesting biology of the Baird's sparrow in southwestern Manitoba. Wilson Bulletin 110:262-270.

Derner, J. D., W. K. Lauenroth, P. Staff, and D. J. Augustine. 2009. Livestock as ecosystem engineers for grassland bird habitat in the western Great Plains of North America. Rangeland Ecology \& Management 62:111-118.

Derner, J. D., and A. J. Whitman. 2009. Plant interspaces resulting from contrasting grazing management in northern mixed-grass prairie: implications for ecosystem function. Rangeland Ecology \& Management 62:83-88.

DieNI, J. S., AND S. L. Jones. 2003. Grassland songbird nest site selection patterns in north-central Montana. Wilson Bulletin 115:388-396.

Dion, N., K. A. Hobson, and S. Larivière. 2000. Interactive effects of vegetation and predators on the success of natural and simulated nests of grassland songbirds. Condor 102:629-634.

Downey, B. L., B. A. Downey, S. L. Frank, D. E. Cross, C. G. DeMaere, D. J. Jarina, R. W. Quinlan, J. Nicholson, and P. F. Jones. 2008. MULTISAR: a Multi-Species Conservation Strategy for Species at Risk in the grassland natural ecoregion of Alberta. Edmonton, AB, Canada: Alberta Sustainable Resource Development, Fish and Wildlife Division. Alberta Species at Risk Report 117. 82 p.

Ecological Framework of Canada. 2011. Ecoregions of Canada: mixed grassland. Available at: http://ecozones.ca/english/region/159.html. Accessed 15 April 2011.

EhrLICH, P. R., D. S. Dobkin, And D. Wheye. 1988. The birder's handbook: a field guide to the natural history of North American birds. Toronto, ON, Canada: Simon \& Shuster. $785 \mathrm{p}$.

Environment CanadA. 2008a. Canadian climate normals or averages 1971-2000: Val Marie, Saskatchewan. Available at: http://climate.weatheroffice.gc.ca/ climate normals/index_e.html. Accessed 10 April 2011.

Environment Canada. 2008b. Recovery strategy for the Sprague's pipit (Anthus spragueii) in Canada. Ottawa, ON, Canada: Environment Canada. 38 p.

Environment Canada. 2010. North American breeding bird survey-Canadian results and analysis website version 3.00. Available at: http://ec.gc.ca/reom-mbs/ default.asp?lang=En\&n=0D74F35F-1. Accessed 9 0ctober 2011.

Filliater, T. S., R. Breitwisch, and P. M. Nealen. 1994. Predation on northern cardinal nests: does choice of nest-site matter? Condor 96:761-768.

Fisher, R. J., AND S. K. Davis. 2011. Habitat use by Sprague's pipits (Anthus spragueii) in native pastures and planted, non-native hay fields. Auk 128:273-282.
Fondell, T. F., and I. J. Ball. 2004. Density and success of bird nests relative to grazing on western Montana grasslands. Biological Conservation 117:203-213.

Giuliano, W. M., AND J. D. Homyack. 2004. Short-term grazing exclusion effects on riparian small mammal communities. Rangeland Ecology \& Management $57: 346-350$.

Government of Canada. 2012. Species at Risk Act Public Registry. Available at: http:// sararegistry.gc.ca. Accessed 30 September 2012.

Grant, W. E., E. C. Birney, N. R. French, and D. M. Swift. 1982. Structure and productivity of grassland small mammal communities related to grazing-induced changes in vegetative cover. Journal of Mammalogy 63:248-260.

Grant, T. A., E. M. Madden, T. L. Shaffer, P. J. Pietz, G. B. Berkey, and N. J. Kadrmas. 2006. Nest survival of clay-colored and vesper sparrows in relation to woodland edge in mixed-grass prairies. Journal of Wildlife Management 70:691-701.

Grant, T. A., T. L. Shaffer, E. M. Madden, and P. J. Pietz. 2005. Time-specific variation in passerine nest survival: new insights into old questions. Auk 122:661-672.

Hammermelster, A., D. Gauthier, and K. McGovern. 2001. Saskatchewan's native prairie: statistics of a vanishing ecosystem and dwindling resource. Saskatoon, SK, Canada: Native Plant Society of Saskatchewan. 17 p.

Harrison, M. L., N. A. Mahony, P. Robinson, A. Newbury, and D. J. Green. 2010. Vesper sparrows and western meadowlarks show a mixed response to cattle grazing in the intermountain region of British Columbia. Avian Conservation and Ecology 5(1):1. Available at: http://ace-eco.org/vol5/iss1/art1.

Harrison, M. L., N. A. Mahony, P. Robinson, A. Newbury, and D. J. Green. 2011. Nestsite selection and productivity of vesper sparrows breeding in grazed habitats. Journal of Field Ornithology 82:140-149.

HART, R. H. 2001. Plant biodiversity on shortgrass steppe after 55 years of zero, light, moderate, or heavy cattle grazing. Plant Ecology 155:111-118.

Hayward, B., E. J. Heske, and C. W. Painter. 1997. Effects of livestock grazing on small mammals at a desert cienga. Journal of Wildlife Management 61:123-129.

Hein, E. W., AND W. S. Hein. 1996. Effect of flagging on predation of artificial duck nests. Journal of Field Ornithology 67:604-611.

Herkert, J. R., D. W. Sample, and R. E. Warner. 1996. Management of midwestern grassland landscapes for the conservation of migratory birds. In: F. R. Thompson [ED.]. Management of midwestern landscapes for the conservation of neotropical migratory birds. Saint Paul, MO, USA: USDA Forest Service North Central Forest Experiment Station. p. 89-116.

HoLt, D. W. 1993. Breeding season diet of short-eared owls in Massachusetts. Wilson Bulletin 105:490-496.

Johnson, M. D., AND C. M. HoRn. 2008. Effects of rotational grazing on rodents and raptors in a coastal grassland. Western North American Naturalist 68:444-452.

Johnston, A. N., And R. G. Anthony. 2008. Small-mammal microhabitat associations and response to grazing in Oregon. Journal of Wildlife Management 72:17361746.

Jones, S. L. 2011. Territory size in mixed-grass prairie songbirds. Canadian FieldNaturalist 125:12-15.

JonES, S. L., AND J. S. DieNI. 2007. The relationship between predation and nest concealment in mixed-grass prairie passerines: an analysis using Program Mark. Studies in Avian Biology 34:117-123.

Kerns, C. K., M. R. Ryan, R. K. Murphy, F. R. Thompson, and C. S. Rubin. 2010. Factors affecting songbird nest survival in northern mixed-grass prairie. Journal of Wildlife Management 74:257-264.

KLEtT, A. T., AND D. H. Johnson. 1982. Variability in nest survival rates and implications to nesting studies. Auk 99:77-87.

KLuG, P. E., S. L. JaCkReL, And K. A. With. 2010. Linking snake habitat use to nest predation risk in grassland birds: the dangers of shrub cover. Oecologia 162:803-813.

Knapp, A. K., J. M. Blair, J. M. Briggs, S. L. Collins, D. C. Hartnett, L. C. Johnson, and E. G. Towne. 1999. The keystone role of bison in North American tallgrass prairie. Bioscience 49:39-50.

KNopf, F. L. 1996. Prairie legacies: birds. In: F. B. Samson and F. L. Knopf [EDS.]. Prairie conservation: preserving North America's most endangered ecosystem. Washington, DC, USA: Island Press. p. 135-148.

Knopf, F. L., and F. B. Samson [Eds.]. 1997. Conservation of grassland vertebrates. In: Ecology and conservation of Great Plains vertebrates. New York, NY, USA: Springer-Verlag. p. 273-289. 
Koper, N., and F. K. A. Schmiegelow. 2007. Does management for duck productivity affect songbird nesting success? Journal of Wildlife Management 71:22492257.

Kresl, S. J., J. T. Leach, C. A. Lively, and R. E. Reynolds. 1996. Working partnerships for conserving the prairie pothole ecosystem. In: F. B. Samson and F. L. Knopf [EDS.]. Prairie conservation: preserving North America's most endangered ecosystem. Washington, DC, USA: Island Press. p. 203-210.

LaPointe, S., J. Giroux, L. Bélanger, and B. Filion. 2000. Benefits of rotational grazing and dense nesting cover for island-nesting waterfowl in southern Quebec. Agriculture, Ecosystems and Environment 78:261-272.

Lusk, J. J., K. Suedkamp Wells, F. S. Guther, And S. D. Fuhlendorf. 2003. Lark sparrow (Chondestes gramamcus) nest-site selection and success in a mixed-grass prairie. Auk 120:120-129.

Lusk, J. S. 2009. The effects of grazing on songbird nesting success in Grasslands National Park of Canada [thesis]. Winnipeg, MB, Canada: University of Manitoba. $77 \mathrm{p}$.

Madden, E. M., R. K. Murphy, A. J. Hansen, and L. Murray. 2000. Models for guiding management of prairie bird habitat in northwestern North Dakota. The American Midland Naturalist 144:377-392.

Maher, W. J. 1973. Birds: I. population dynamics. Saskatoon, SK, Canada: Canadian Committee for the International Biological Programme. Matador Project, Technical Report 34. 56 p.

MARTIN, T. E. 1993. Nest predation and nest sites: new perspectives on old patterns. Bioscience 43:523-532.

Matlack, R. S., D. W. Kaufman, and G. A. Kaufman. 2001. Influence of grazing by bison and cattle on deer mice in burned tallgrass prairie. American Midland Naturalist 146:361-368.

McMaster, D. G., J. H. Devries, and S. K. Davis. 2005. Grassland birds nesting in haylands of southern Saskatchewan: landscape influences and conservation priorities. Journal of Wildlife Management 69:211-221.

Murray, G. B., and B. M. Vestal. 1979. Effects of environmental structure on the burrow distribution of thirteen-lined ground squirrels, Spermophilus tridecemlineatus (Sciurdae). Southwestern Naturalist 24:79-86.

NACK, J. L., AND C. A. RiBIC. 2005. Apparent predation by cattle at grassland bird nests. Wilson Bulletin 117:56-62.

NakagawA, S. 2004. A farewell to Bonferroni: the problems of low statistical power and publication bias. Behavioral Ecology 15:1044-1045.

Nelson, K. S., E. M. Gray, and J. R. Evans. 2011. Finding solutions for bird restoration and livestock management: comparing grazing exclusions levels. Ecological Applications 21:547-554.

Nernderg D., and D. Ingstrup. 2005. Prairie conservation in Canada: the Prairie Conservation Action Plan experience. Asilomar, CA, USA: USDA Forest Service. PSW-GTR-191. 7 p.

Pietz, P. J., and D. A. Granfors. 2000. Identifying predators and fates of grassland passerine nests using miniature video cameras. Journal of Wildlife Management 64:71-87.

Quinn, G. P., and M. J. Keough. 2002. Experimental design and data analysis for biologists. New York, NY, USA: Cambridge University Press. 537 p.

ReED, J. M. 1986. Vegetation structure and vesper sparrow territory location. Wilson Bulletin 98:144-147.

RenfreW, R. B., AND C. A. RiBIC. 2003. Grassland passerine nest predators near pasture edges identified on videotape. Auk 120:371-383.

RICKLEFS, R. E. 1969. An analysis of nesting mortality in birds. Washington, DC, USA: Smithsonian Institution Press. Smithsonian Contributions to Zoology No. 9. 48 p.
Robel, R. J., J. N. Briggs, A. D. Dayton, and L. C. Hulbert. 1970. Relationships between visual obstruction measurements and weight of grassland vegetation. Journal of Range Management 23:295-297.

Rotella, J. J., S. J. Dinsmore, and T. L. Shaffer. 2004. Modeling nest-survival data: a comparison of recently developed methods that can be implemented in MARK and SAS. Animal Biodiversity and Conservation 27:187-205.

SAaB, V. A., C. E. Bock, T. D. Rich, And D. S. Dobkin. 2005. Livestock grazing effects in western North America. In: T. M. Martin and D. M. Finch [EDS.]. Ecology and management of neotropical migratory birds: a synthesis and review of critical issues. New York, NY, USA: Oxford University Press. p. 311-353.

Sauer, J. R., J. E. Hines, and J. Fallon. 2008. The North American breeding bird survey, results and analysis 1966-2007. Version 2007.0.0. Laurel, MD, USA: USGS Patuxent Wildlife Research Center. Available at: http://www.mbr-pwrc. usgs.gov/bbs/bbs2007.html. Accessed 22 May 2008.

Schaeff, C., and J. Picman. 1988. Destruction of eggs by western meadowlarks. Condor 90:935-937.

Shaffer, T. L. 2004. A unified approach to analyzing nest success. Auk 121:526-540.

Skagen, S.K., and A. A. Yackel Adams. 2010. Are there optimal densities for prairie birds? Condor 112:8-14.

Sмiтt, H., AND J. Sмiтt. 1966. A breeding bird survey on uncultivated grassland at Regina. Blue Jay 24:129-131.

SUTTER, G. C. 1997. Nest-site selection and nest-entrance orientation in Sprague's pipit. Wilson Bulletin 109:462-469.

Sutter, B., And G. Ritchison. 2005. Effects of grazing on vegetation structure, prey availability, and reproductive success of grasshopper sparrows. Journal of Field Ornithology 76:345-351.

Taylor, B. L., And T. GerRodette. 2002. The uses of statistical power in conservation biology: the vaquita and northern spotted owl. Conservation Biology 7:489-500.

Temple, S. A., B. R. Fevold, L. K. Paine, D. J. Undersander, and D. W. Sample. 1999. Nesting birds and grazing cattle: accommodating both on midwestern pastures. Studies in Avian Biology 19:196-202.

Towne, E. G., D. C. Hartnett, and R. C. Cochran. 2005. Vegetation trends in tallgrass prairie from bison and cattle grazing. Ecological Applications 15:1550-1559.

Vickery, P. D., M. L. Hunter, and J. V. Wells. 1992. Evidence of incidental nest predation and its effects on nests of threatened grassland birds. Oikos 63:281288.

WEIDINGER, K. 2002. Interactive effects of concealment, parental behaviour, and predators on the survival of open passerine nests. Journal of Animal Ecology 71:424-437.

WiENS, J. A. 1973. Pattern and process in grassland bird communities. Ecological Monographs 43:237-270.

Winter, M. 1999. Relationship of fire history to territory size, breeding density, and habitat of Baird's sparrow in North Dakota. Studies in Avian Biology 19:171-177.

Winter, M., D. H. Johnson, And J. A. Shaffer. 2005. Variability in vegetation effects on density and nesting success of grassland birds. Journal of Wildlife Management 69:185-197.

Wiтн, K. A. 1994. The hazards of nesting near shrubs for a grassland bird, the McCown's longspur. Condor 96:1009-1019.

Yackel Adams, A. A., S. K. Skagen, and R. D. Adams. 2001. Movements and survival of lark bunting fledglings. Condor 103:643-647.

Yackel Adams, A. A., S. K. Skagen, and J. A. Savidge. 2007. Population-specific demographic estimates provide insights into declines of lark buntings (Calamospiza melanocorys). Auk 124:578-593. 